Palestine Exploration Quarterly

\title{
Zion and Ophel
}

\section{J. M. Tenz}

To cite this article: J. M. Tenz (1885) Zion and Ophel, Palestine Exploration Quarterly, 17:2, 121-123, DOI: 10.1179/peq.1885.17.2.121

To link to this article: http://dx.doi.org/10.1179/peq.1885.17.2.121

曲 Published online: 20 Nov 2013.

Submit your article to this journal 준

Џll Article views: 5

Q View related articles $\asymp$ 
Mr. Kennion concludes by propounding his own theory, which is, that the district of Emmaus in Josephus "lay along the valley that has Kolonieh at its southern extremity," and that the village in Luke "was near the head of that valley, and reaching on to Kubeibeh." It is his old opinion, which he finds it hard to give up in favour of Mrs. Finn, whom, however, he thanks "for her valuable contribution to the discussion."

I have already referred to the claims of Kubeibeh, which really have no weight in the presence of Mrs. Finn's discovery. As for the district heginning at Kolonieh, four miles from Jerusalem, it is impossible that Josephus, who knew the district well, could have said that it was $7 \frac{1}{2}$ niles from the city. The proposil of this site nust therefore be regarded as utterly untenable. But no discovery of baths is mentioned at Kubeibeh; and the reader now perceives why the writer was led into the error of asserting that Josephus explained Emmaus to mean hot springs, and that baths were not necessary to every Emmaus. $\mathrm{He}$ shuts his eyes against the flood of light which Mrs. Finn has thrown on the subject, and says: "One conclusion is indisputable, that no other" location of St. Luke's Emmaus could by any possibility combine so many rays of light as converge upon the Wâdy Buwai." His conclusion is not only disputed, but we may pronounce it utterly impossible to accept the site he proposes. All was doubt and uncertainty about the site of Emmaus till the publication of Mrs. Finn's paper ; but now all appears clear and certain.

Coldstream.

\section{ZION AND OPHEL.}

By J. M. Tenz.

Mr. Birch and Dr. A. H. Sayce are confident that Mount Zion stood on the south side of the Temple mount which descends down to the lowest part of the valleys surrounding Jerusalem, and Dr. Sayce, in his "Topography of Præ-exilic Jerusalem," in the last Quarterly Statement, takes it for granted that it is no longer possible to deny it. Yet the valley which Dr. Sayce shows in his sketch map to divide Ophel from his little Mount Zion on the lowest hill of the city has no existence.

We may also justify the remarks made by Captain Conder in reply to Mr. Birch on the same subject in the last Quarterly Statement.

Josephus, the great historian of the Jews, who is so much blamed for his errors, and attributed errors, is yet the most reliable authority, as it has in many cases been proved by recent discoveries.

Having for many years taken great interest in the history of Jerusalem, the Temple, and the discoveries made from time to time by exploring 
parties, and having also carefully constructed a model of that city when in the time just before its destruction by Titus, I may be permitted to give my opinion on the topography of ancient Jerusalem.

The "upper city" of Josephus answers to all requirements of Mount Zion, the City of David. "Walk about Zion, and go round about her, tell the towers thereof, mark ye well her bulwarks, and consider her palaces:" means many towers, extensive walls, numbers and important palaces, which could not have all been placed on the lower slope of the Templehill, which by Josephus is called the suburb.

In a military point of view we may naturally suppose that the uppermost hill was "Mount Zion, the stronghold of the Jebusites." History and recent discoveries support it. When the Israelites took possession of their promised land, Jerusalem fell to the lot of Benjamin (5 "Ant.," i, 22), "but the Jebusites who inhabited it were not driven out until the time of David," "and the border went up by the valley of the son of Hinnom unto the south side of the Jebusite; the same is Jerusalem" (Josh. xv, 8). This passage sufficiently indicates that the border went up by the south valley, which is now called valley of Hinnom. The Tomb of David may also be looked for at or near the traditional site, which is over against, or near "the pool that was made" (Neh. iii, 16), which may well be the socalled lower Pool of Gihon, once one of the largest pools at Jerusalem.

The Dragon Well may be identified with the Virgin's Well.

On the arrival of Nehemiah at Jerusalem, the Temple was partly rebuilt by Zerubbabel ; the king's high house (the site of which was in later years joined to the outer court of the Temple by Herod the Great) was probably restored, and the Nethinims had dwellings in Ophel; Nehemiah would have taken up his residence there, as the other parts of the city were still in ruins. On his night journey he would have proceeded from Ophel to the valley gate before the Dragon Well (Virgin's Well), then went on to the dung gate, probably the same as the gate between two walls near the Pool of Siloam, then to the fountain gate, a gate leading to the upper city. After he went up by the brook (Brook Gihon and Valley of Hinnom), then returned and entered by the valley gate (Neh. ii, 12-15).

Further explorations may result in the discovery of the site of the east, or Shushan gate, which according to the Talmud stood over against the east front of the Temple. Thus we would obtain the exact line from east to west through the centre of the Altar, which, I believe, stood on the rock in the Great Mosque. It has also been remarked, in one of the Quarterly Statements, that the sacred cubit, which is said to have been marked on the sides of the Shushan gate, may yet be found on the lower part, which must have been below the level of the court, with steps to descend to a much lower level of the ground outside the wall, but which is now to a great extent filled up. The discovery of that gate would therefore be of great importance.

It is still my impression that some remains of the second wall may yet be found on the east side of the Church of the Holy Sepulchre. It is quite possible that that church may cover the site of Calvary and the garden of 
Joseph of Arimathea. Although, according to the Talmud, the place of stoning, and the discoveries of the ruins of St. Stephen's Church outside the Damascus gate, may favour Captain Conder's views of his supposed Calvary on a hill just outside that gate, yet the traditional site, which dates at least back to the time of the Empress Helena, ought not to be disputed until further discoveries can be made.

We sincerely hope that the Palestine Exploration Fund Society will be able to continue their work of exploration at Jerusalem, which is the only means to lead us to a satisfactory result.

December 10th, 1883.

\section{CAPTAIN CONDER AND KADESH-BARNEA.}

\section{By the Rev. H. Clay Trumbill.}

INASMUCH as Captain Conder has given special prominence, in the Quarterly Statement, to my volume on Kadesh-Barnea, as worthy of consideration in the settlement of a pivotal point in the lower boundary of Palestine, I venture to ask the privilege of calling attention to the main purpose of that volume-which he has not touched by his comments.

In "Kadesh-Barnea," I have subjected every Biblical mention of that ancient site to an examination, and have compared them all with each other, showing, as I believe, that many of them absolutely require its location at or near the site of 'Ayn Qadees, and that every one of them is consistent with that location; hence that there and there only its identification is properly to be looked for. If I am right as to this consensus of Biblical evidence, it follows that even if a Kadesh-Barnea be actually discovered elsewhere, it cannot, by any possibility, be the Kadesh-Barnea of the Bible-text.

This basal portion of my volume is, as I have said, left untouched by Captain Conder's criticisms ; and if, indeed, he were found to be correct at every one of his more than twenty noted points of difference with my incidental suggestions of confirmatory evidence of the identification of 'Ayn Qadees, my claim that there is the site of Kadesh-Barnea would remain as strong as before, in spite of such errors in my confirmatory collatings.

But, lest Captain Conder's long list of apparent mistakes on my part should throw discredit on the really important portion of the volume, not dealt with by him, and so should deter from its examination those who know of it only from his criticisms, I desire to say, that after a careful reexamination of every point to which Captain Conder has taken exception, I am of the opinion that at no one of them has he shown an error in the work he criticises, while in a number of cases his own position is clearly untenable. Let me name a few illustrative instances. 